\author{
PATRYK TOMASZEWSKI
}

Uniwersytet Mikołaja Kopernika

ORCID: 0000-0002-2333-9256

\title{
Programy studiów Stosunków Międzynarodowych na Uniwersytecie Mikołaja Kopernika w Toruniu w ocenie studentów i interesariuszy
}

\section{International Relations study programmes at the Nicolaus Copernicus University in Toruń in the opinions of students and co-operators}

The purpose of this article is to present an assessment of study programmes in the field of international relations from the point of view of students of the Faculty of Political Science and International Studies of the Nicolaus Copernicus University and its co-operators. It primarily concerns the didactic offer, internationalisation of the programme and professional internships.

Keywords: international relations, student ratings, utility

Słowa kluczowe: stosunki międzynarodowe, oceny studentów, upraktycznienie

\section{Wstęp}

Stosunki międzynarodowe jako kierunek studiów cieszą się szczególnym zainteresowaniem od połowy lat dziewięćdziesiątych XX w., ale ośrodkiem o najstarszych w Polsce tradycjach jest Uniwersytet Warszawski, gdzie od 1976 r. jako samodzielna jednostka działa Instytut Stosunków Międzynarodowych ${ }^{1}$. Zainteresowanie studiami o takim profilu spowodowało wzrost oferty

$1 \quad \mathrm{Na}$ Uniwersytecie Wrocławskim kierunek Stosunki Międzynarodowe otwarto w 1998 r., a na Uniwersytecie Marii Curie-Skłodowskiej - w 2000. Zob. O Instytucie Studiów Międzynarodowych UWr, „Uniwersytet Wrocławski” [online, dostęp: 10 VI 2019], dostępny w internecie: < https://www.ism.uni.wroc.pl/Instytut/O-Instytucie-Studiow-Miedzynarodowych-UWr>; Historia, „Wydział Politologii UMCS” [online, dostęp: 10 VI 2019], dostępny w internecie: $<$ https://www.umcs.pl/pl/historia,586.htm>. 
akademickiej² ${ }^{2}$ Nowy kierunek powstawał zazwyczaj w oparciu kadrę naukową wywodzącą się spośród historyków dyplomacji, politologów zajmujących się stosunkami międzynarodowymi oraz specjalistów od prawa międzynarodowego.

W Toruniu Stosunki Międzynarodowe powstały 1 maja 1999 r. przy Zakładzie Stosunków Międzynarodowych funkcjonującym w ramach Instytutu Historii i Archiwistyki Wydziału Nauk Historycznych Uniwersytetu Mikołaja Kopernika. Kierownikiem zakładu został historyk dyplomacji i były rektor toruńskiej wszechnicy prof. dr hab. Sławomir Kalembka. Zadaniem jednostki było prowadzenie działalności dydaktycznej i naukowo-badawczej w zakresie stosunków międzynarodowych XIX i XX w., ze szczególnym uwzględnieniem kontaktów Polski ze wschodnimi sąsiadami oraz krajami Europy Zachodniej. Kolejnym krokiem było utworzenie 1 kwietnia 2000 r. Katedry Stosunków Międzynarodowych - samodzielnej jednostki organizacyjnej, która przejęła w całości zadania dydaktyczne i naukowe. 1 maja kierownikiem katedry został dr hab. Zbigniew Karpus, prof. UMK. Dynamiczny rozwój jednostki i zwiększenie liczby samodzielnych pracowników doprowadziło do przekształcenia jej 1 marca 2005 r. w Instytut Stosunków Międzynarodowych. Obecnie kierunek Stosunki Międzynarodowe prowadzony jest przez Wydział Politologii i Studiów Międzynarodowych, działający od 1 września 2009 r. na podstawie Uchwały nr 2 Senatu Uniwersytetu Mikołaja Kopernika w Toruniu z dnia 31 marca 2009 r., na mocy której połączono Instytut Nauk Politycznych i Instytut Stosunków Międzynarodowych ${ }^{3}$.

Pierwsza dekada funkcjonowania kierunku Stosunki Międzynarodowe na UMK była bardzo udana pod względem rekrutacyjnym - w ciągu pierwszych pięciu lat liczba kandydatów wahała się od siedmiu do dziewięciu osób na jedno miejsce ${ }^{4}$. Obecnie jest on drugim wyborem 80 proc. studentów, a liczba zainteresowanych spadła o 75 proc., co musi skłaniać do refleksji, gdyż przyczyn tego stanu rzeczy nie można szukać wyłącznie w niżu demograficznym.

Celem niniejszego tekstu jest przedstawienie oceny programów studiów na kierunku Stosunki Międzynarodowe z punktu widzenia studentów Wydziału Politologii i Studiów Międzynarodowych UMK oraz współpracujących z nim

2 O instytucjonalizacji stosunków międzynarodowych zob. Nauka o stosunkach międzynarodowych i studia europejskie w Polsce, red. J. Czaputowicz, K. Ławniczak, A. Wójciuk, Wydawnictwo Naukowe „Scholar”, Warszawa 2015, s. 45-68.

3 O wydziale, ,Uniwersytet Mikołaja Kopernika w Toruniu. Wydział Politologii i Stosunków Międzynarodowych" [online, dostęp: 10 VI 2019], dostępny w internecie: <https:// www.wpism.umk.pl/wydzial/o-wydziale/>.

4 Rozmowa ze współtwórcą kierunku na UMK, dr. hab. prof. UMK Zbigniewem Karpusem. 
interesariuszy. Dotyczy ona przede wszystkim oferty dydaktycznej, umiędzynarodowienia kierunku oraz praktyk zawodowych.

\section{Metodologia}

W celu uzyskania danych na interesujący nas temat przeprowadzono dwa badania - jedno metodą ilościową z użyciem techniki ankietowej PAPI, a drugie metodą jakościową, $\mathrm{w}$ formie wywiadu swobodnego $\mathrm{z}$ pewnymi cechami fokusowego ${ }^{5}$. Założeniem ankiety było przeprowadzenie badań wyczerpujących, a dobór próby był celowy. Okazało się jednak, że liczba studentów uczęszczających na zajęcia z programu interesujących nas lat studiów (drugi rok magisterskich i trzeci licencjackich) jest znacznie mniejsza, niż wynikałoby z danych uczelni. Nawet pod koniec roku akademickiego ankieter nie mógł trafić na pełną grupę słuchaczy. Ich absencja ma różne podłoże. Cześć studentów powtarza rok, nie mając zaliczonego jedynie seminarium, w związku z czym nie bierze udziału w zajęciach. Zdarzają się przy tym osoby, które powtarzają ten schemat przez kilka lat, a szczególnie sporo jest ich na studiach drugiego stopnia, gdzie mają do zaliczenia jedynie seminarium magisterskie. Są też tzw. martwe dusze, czyli studenci, którzy z jakiegoś powodu nawet nie zapisali się na zajęcia.

Badania w oparciu o wywiad swobodny prowadzone były pośród pracodawców i otoczenia społecznego współpracującego z Wydziałem Politologii i Studiów Międzynarodowych UMK.

Tabela 1. Liczba studentów biorących udział w badaniu ankietowym

\begin{tabular}{|l|c|}
\hline \multicolumn{1}{|c|}{ Rok studiów } & Liczba studentów \\
\hline $\begin{array}{l}\text { Rok akademicki 2017/2018 } \\
\text { licencjat }\end{array}$ & 35 \\
\hline $\begin{array}{l}\text { Rok akademicki 2018/2019 } \\
\text { licencjat }\end{array}$ & 39 \\
\hline $\begin{array}{l}\text { Rok akademicki 2017/2018 } \\
\text { magisterium }\end{array}$ & 38 \\
\hline $\begin{array}{l}\text { Rok akademicki 2018/2019 } \\
\text { magisterium }\end{array}$ & 41 \\
\hline
\end{tabular}

Źródło: oprac. własne

5 Spotkanie zostało zorganizowane 28 V 2019 r. na Wydziale Politologii i Studiów Międzynarodowych. Jego celem było poznanie oczekiwań otoczenia społecznego i biznesowego w zakresie sylwetki studentów i absolwentów kierunków związanych z obszarem nauk o polityce i stosunków międzynarodowych oraz ocena wiedzy i umiejętności studentów pracujących w zawodach i instytucjach związanych z tą dyscypliną. 
Należy dodać, że badania ankietowe prowadzone były w roku akademickim 2017/2018 i 2018/2019 i miały charakter sondażowy. Wzięło w nich udział łącznie 96 studentów, w tym 54 z roku akademickiego 2017/2018 ( $28 \mathrm{z}$ trzeciego roku studiów licencjackich i $26 \mathrm{z}$ drugiego magisterskich) oraz 42 z roku akademickiego 2018/2019 ( 25 z licencjackich i 17 z magisterskich).

Celem badania było uzyskanie odpowiedzi na pięć pytań:

1. Co oznacza dla Pani/Pana upraktycznienie zajęć?

2. Jak ocenia Pani/Pan program zajęć?

3. Jakie przedmioty wprowadził(a)by Pani/Pan na studiach?

4. Czy korzysta Pani/Pan z umiędzynarodowienia?

5. Jak ocenia Pani/Pan wsparcie uczelni w znalezieniu praktyk i odbywaniu staży?

W pytaniach drugim i piątym ocenę studentów badano za pomocą skali Likerta $^{6}$.

\section{Wyniki}

1. W pytaniu wielokrotnego wyboru „Co oznacza dla Pani/Pana upraktycznienie zajęć?" respondenci mogli wskazać następujące odpowiedzi:

- zajęcia prowadzone przez praktyków, np. obecnych lub byłych dyplomatów, wojskowych biorących udział w misjach międzynarodowych itp.;

- zajęcia, na których rozwiązuje się case study;

- więcej zajęć laboratoryjnych w małych grupach;

- więcej praktyk studenckich;

- odpowiedź własna.

Pierwszą odpowiedź wskazały 42 osoby, tj. 43 proc. badanych, przy czym warto podkreślić, że aż 24 były studentami drugiego stopnia. Wskazało ją więc 79 proc. badanych z tej grupy, a jedynie 34 proc. ze stopnia pierwszego. Odpowiedź dotyczącą rozwiązywania konkretnych zagadnień problemowych zaznaczyło aż 90 osób, czyli prawie 94 proc. badanych. Zajęcia laboratoryjne w małych grupach wskazało 85 osób, czyli 89 proc. I tu widoczna była przewaga studentów drugiego stopnia: zaznaczyło ją aż 91 proc. z nich, a spośród studentów pierwszego stopnia -87 proc. Dodatkowych praktyk oczekiwało tylko 25 badanych.

6 Na temat badań z zastosowaniem tego narzędzia zob. J. Jezior, Metodologiczne problemy zastosowania skali Likerta $w$ badaniach postaw wobec bezrobocia, „Przegląd Socjologiczny" 2013, t. 62, nr 3, s. 117-138. 
Wykorzystując opcję własnej odpowiedzi, 12 osób wymieniło wyjazdy do różnych instytucji związanych ze stosunkami międzynarodowymi (podawano nie tylko Ministerstwo Spraw Zagranicznych, ale również firmy zajmujące się handlem zagranicznym), a 7 - wycieczki zagraniczne.

2. Rezultaty odpowiedzi na pytanie drugie, mające na celu zbadanie oceny programu studiów w skali Likerta, przedstawia tabela 2 .

Tabela 2. Odpowiedzi na pytanie: „Jak ocenia Pani/Pan program zajęć?”

\begin{tabular}{|l|c|c|c|c|c|}
\hline \multirow{2}{*}{$\begin{array}{c}\text { Stopień } \\
\text { studiów }\end{array}$} & \multicolumn{5}{|c|}{ Ocena } \\
\cline { 2 - 6 } & bardzo dobrze & dobrze & nie mam zdania & źle & bardzo źle \\
\hline Pierwszy & 17 & 27 & 3 & 5 & 1 \\
\hline Drugi & 10 & 16 & 8 & 7 & 3 \\
\hline
\end{tabular}

Źródło: oprac. własne

3. Odpowiadając na pytanie dotyczące oczekiwań co do wprowadzenia nowych obszarów tematycznych bądź zwiększenia liczby godzin tych już obecnych w programie, ankietowani mogli zaznaczyć dowolną liczbę z następujących odpowiedzi:

- przedmioty związane z historią dyplomacji;

- przedmioty związane z historią krajów i regionów;

- przedmioty ekonomiczne;

- przedmioty związane z integracją europejską;

- zajęcia prowadzone w języku angielskim;

- zajęcia w innym języku obcym (w jakim?);

- przedmioty dotyczące praktycznego wymiaru dyplomacji;

- przedmioty związane z obszarem postsowieckim;

- przedmioty dotyczące zagadnień Azji i Pacyfiku;

- przedmioty dotyczące współczesnego bezpieczeństwa międzynarodowego;

- przedmioty dotyczące obszaru Europy Środkowo-Wschodniej;

- przedmioty dotyczące handlu zagranicznego;

- przedmioty dotyczące zagadnień kulturowych i cywilizacyjnych;

- zagadnienia związane z prawem międzynarodowym;

- odpowiedź własna ${ }^{7}$.

$7 \quad$ Tak duża liczba opcji wyboru wynikała $\mathrm{z}$ faktu, że w sylabusach pojawiają się prawie wszystkie zagadnienia z zakresu polityki międzynarodowej, polityki bezpieczeństwa czy też różnych obszarów świata. 
Tabela 3. Preferencje badanych odnośnie do wprowadzenia przedmiotów z konkretnych obszarów badawczych

\begin{tabular}{|c|c|c|}
\hline Odpowiedź & $\begin{array}{c}\text { Wskazania studentów } \\
\text { pierwszego stopnia }\end{array}$ & $\begin{array}{l}\text { Wskazania studentów } \\
\text { drugiego stopnia }\end{array}$ \\
\hline $\begin{array}{l}\text { Przedmioty związane z historią } \\
\text { dyplomacji }\end{array}$ & $11 \%$ & $9 \%$ \\
\hline $\begin{array}{l}\text { Przedmioty związane } \mathrm{z} \text { historią } \\
\text { krajów i regionów }\end{array}$ & $17 \%$ & $16 \%$ \\
\hline Przedmioty ekonomiczne & $11 \%$ & $16 \%$ \\
\hline $\begin{array}{l}\text { Przedmioty związane z integracją } \\
\text { europejską }\end{array}$ & $8 \%$ & $6 \%$ \\
\hline $\begin{array}{l}\text { Zajęcia prowadzone w języku } \\
\text { angielskim }\end{array}$ & $26 \%$ & $16 \%$ \\
\hline $\begin{array}{l}\text { Zajęcia w innym języku obcym } \\
\text { (w jakim?) }\end{array}$ & $15 \% *$ & $14 \% * *$ \\
\hline $\begin{array}{l}\text { Przedmioty dotyczące praktycznego } \\
\text { wymiaru dyplomacji }\end{array}$ & $28 \%$ & $12 \%$ \\
\hline $\begin{array}{l}\text { Przedmioty związane z obszarem } \\
\text { postsowieckim }\end{array}$ & $8 \%$ & $16 \%$ \\
\hline $\begin{array}{l}\text { Przedmioty dotyczące zagadnień } \\
\text { Azji i Pacyfiku }\end{array}$ & $11 \%$ & $19 \%$ \\
\hline $\begin{array}{l}\text { Przedmioty dotyczące współczesnego } \\
\text { bezpieczeństwa międzynarodowego }\end{array}$ & $43 \%$ & $22 \%$ \\
\hline $\begin{array}{l}\text { Przedmioty dotyczące obszaru } \\
\text { Europy Środkowo-Wschodniej }\end{array}$ & $28 \%$ & $25 \%$ \\
\hline $\begin{array}{l}\text { Przedmioty dotyczące handlu } \\
\text { zagranicznego }\end{array}$ & $21 \%$ & $28 \%$ \\
\hline $\begin{array}{l}\text { Przedmioty dotyczące zagadnień } \\
\text { kulturowych i cywilizacyjnych }\end{array}$ & $11 \%$ & $16 \%$ \\
\hline $\begin{array}{l}\text { Zagadnienia związane z prawem } \\
\text { międzynarodowym }\end{array}$ & $6 \%$ & $6 \%$ \\
\hline Odpowiedź własna & $\begin{array}{l}\text { bezpieczeństwo } \\
\text { militarne Polski } \\
(2 \text { osoby), } \\
\text { migracje ( } 3 \text { osoby), } \\
\text { ocieplenie klimatu } \\
(1 \text { osoba }) \\
\end{array}$ & $\begin{array}{l}\text { uchodźcy ( } 2 \text { osoby), } \\
\text { terroryzm międzynarodowy } \\
(1 \text { osoba), } \\
\text { zagadnienia polityki } \\
\text { zagranicznej państw } \\
\text { Ameryki Łacińskiej (1 osoba) }\end{array}$ \\
\hline \multicolumn{3}{|c|}{$\begin{array}{l}\text { * Odpowiedź wskazało } 8 \text { ankietowanych: } 4 \text { osoby wymieniły język rosyjski, } 2 \text { niemiecki, } \\
1 \text { francuski, } 1 \text { hiszpański. } \\
\text { ** Odpowiedź wskazało } 6 \text { ankietowanych: } 3 \text { osoby wymieniły język rosyjski, } 1 \text { hiszpański, } \\
2 \text { niemiecki. }\end{array}$} \\
\hline
\end{tabular}

Źródło: oprac. własne

4. W pytaniu dotyczącym umiędzynarodowienia respondenci mieli do wyboru cztery odpowiedzi i możliwość przedstawienia własnych propozycji: 
- więcej zajęć prowadzonych przez wykładowców obcokrajowców;

- więcej programów wyjazdów na studia zagraniczne (jak Erasmus + );

- krótkie wyjazdy na zajęcia zagraniczne (jak wyjazdy studyjne, szkoły letnie);

- praktyki poza granicami kraju;

- inne.

Tabela 4. Formy umiędzynarodowienia studiów oczekiwane przez badanych

\begin{tabular}{|l|c|c|}
\hline \multicolumn{1}{|c|}{ Odpowiedź } & $\begin{array}{c}\text { Wskazania studentów } \\
\text { pierwszego stopnia }\end{array}$ & $\begin{array}{c}\text { Wskazania studentów } \\
\text { drugiego stopnia }\end{array}$ \\
\hline $\begin{array}{l}\text { Więcej zajęć prowadzonych przez } \\
\text { wykładowców obcokrajowców }\end{array}$ & $19 \%$ & $11 \%$ \\
\hline $\begin{array}{l}\text { Więcej programów wyjazdów na studia } \\
\text { zagraniczne (jak Erasmus+) }\end{array}$ & $26 \%$ & $44 \%$ \\
\hline $\begin{array}{l}\text { Krótkie wyjazdy na zajęcia zagraniczne } \\
\text { (jak wyjazdy studyjne, szkoły letnie) }\end{array}$ & $58 \%$ & $9 \%$ \\
\hline Praktyki poza granicami kraju & $19 \%$ & $35 \%$ \\
\hline Inne & $9 \% *$ & $5 \% * *$ \\
\hline$* 3$ osoby napisały, że wyjazdy z programu Erasmus Plus powinny się zaczynać już \\
na pierwszym roku studiów, 1 osoba, że powinny się pojawić obozy letnie, a 1 za istotną \\
uznała możliwość zdobycia podwójnego dyplomu. \\
$* * 2$ osoby wymieniły możliwość zdobycia podwójnego dyplomu. \\
\hline
\end{tabular}

Źródło: oprac. własne

5. Ostatnie pytanie dotyczyło pomocy uczelni w rozpoczęciu staży i praktyk. Oprócz udzielenia odpowiedzi na skali Likerta ankietowani mieli możliwość wypisania własnych uwag.

Tabela 5. Ocena pomocy udzielanej przez uczelnię w znalezieniu praktyk i staży

\begin{tabular}{|l|c|c|c|c|c|}
\hline \multirow{2}{*}{$\begin{array}{c}\text { Stopień } \\
\text { studiów }\end{array}$} & \multicolumn{5}{|c|}{ Odpowiedzi } \\
\cline { 2 - 6 } & bardzo dobrze & dobrze & nie mam zdania & źle & bardzo źle \\
\hline Pierwszy & 10 & 14 & 7 & 15 & 7 \\
\hline Drugi & 4 & 4 & 27 & 5 & 2 \\
\hline
\end{tabular}

Źródło: oprac. własne

W części otwartej poruszano przede wszystkim problemy proponowanych w czasie roku akademickiego staży (zazwyczaj związanych z firmami) oraz zbyt małego katalogu instytucji, w których można odbywać praktyki. 
Drugie badanie realizowane było poprzez wywiady swobodne z interesariuszami w roku akademickim 2017/2018 oraz wywiady swobodne przypominające badania fokusowe w roku 2018/2019 (w tych ostatnich grupa badanych była niestety mała). Trzej rozmówcy byli konsulami honorowymi (dwaj jednocześnie przedsiębiorcami), a dwaj przedsiębiorcami działającymi na rynkach zagranicznych. Pytania dotyczyły zdobytych podczas studiów kompetencji praktykantów (wiedzy, umiejętności i kompetencji miękkich), a także możliwości odbywania staży.

Badani w roku 2017/2018 wskazywali, że część studentów, z którymi się spotkali, w niedostatecznym stopniu włada językiem angielskim. Brakuje im też kompetencji miękkich, przede wszystkim kreatywności i zaangażowania. Na pytanie o pożądaną sylwetkę praktykanta, a w przyszłości pracownika, zawsze i bez wyjątku rozmówcy odpowiadali, że spodziewają się osoby kreatywnej z szeroką wiedzą ogólną, ponieważ wiedzy specjalistycznej osoba ta nabędzie w czasie praktyk i pracy. Podczas rozmowy wypracowaliśmy formułę staży, ale niestety tylko dla wąskiego grona najbardziej zainteresowanych i ukierunkowanych studentów stosunków międzynarodowych.

W roku akademickim 2018/2019 przeprowadzono wywiad z dwoma przedstawicielami urzędu pracy i jednym urzędu marszałkowskiego. Interesariusze odpowiadali, jaka sylwetka absolwenta poszukiwana jest na rynku pracy. Przedstawiciele urzędu pracy mówili, że pracodawcy poszukują osób z kompetencjami miękkimi, umiejętnością pracy $\mathrm{w}$ grupie, samodzielnie rozwiązujących problemy i kreatywnych; jako ważną wymienili też znajomość języka specjalistycznego (np. Business English czy Legal English) oraz drugiego języka obcego. Rozmówcy wskazali potrzebę prowadzenia specjalistycznego przedmiotu dotyczącego praktycznych aspektów pracy w administracji, a ponadto kształcenia umiejętności efektywnego wyszukiwania informacji w Internecie i budowania wiedzy na temat e-administracji. Zauważyli też, że bardzo mało osób ma umiejętności w zakresie wystąpień publicznych ${ }^{8}$.

\section{Analiza wyników badań ankietowych}

Badania prowadzone wśród słuchaczy trzeciego roku studiów licencjackich i drugiego uzupełniających na kierunku Stosunki Międzynarodowe miały charakter sondażowy. Należy z nich wyciągnąć kilka wniosków. Przede

8 Nagranie rozmowy z 22 V 2019 r., w posiadaniu autora. 
wszystkim pogram studiów pierwszego i drugiego stopnia powinien się różnić. Z odpowiedzi studentów drugiego stopnia wynika, że zajęcia na tym etapie mogłyby mieć znacznie bardziej specjalistyczny charakter, powinny być prowadzone przez praktyków, np. obecnych i byłych dyplomatów, wojskowych biorących udział w misjach międzynarodowych czy też specjalistów z think-tanków. Studenci widzą potencjał w zajęciach, na których rozwiązuje się konkretne zagadnienia problemowe - taką odpowiedź zaznaczyło 94 proc. badanych. Co istotne, umiejętności w tym zakresie oczekują od absolwentów interesariusze.

Program studiów oceniony został dobrze i bardzo dobrze zarówno wśród studentów pierwszego, jak i drugiego stopnia. Więcej pozytywnych ocen wśród słuchaczy pierwszego stopnia (83 proc. wobec 59 proc. wśród magistrantów) wynika prawdopodobnie z faktu, że mają oni mniejsze doświadczenie studiowania, a co za tym idzie - brak punktu odniesienia. Wśród studentów drugiego stopnia znajdują się także absolwenci innych uczelni i innych kierunków, których doświadczenia mogły wpłynąć na oczekiwania, a co za tym idzie - na wyniki badania.

Dużym problemem jest przebieg praktyk. Część studentów traktuje je niestety wyłącznie jako konieczność, a nie szansę rozwoju kompetencji. $\mathrm{Z}$ drugiej strony rynek praktyk w Toruniu i ościennych powiatach, $\mathrm{z}$ których wywodzi się znaczna część studentów stosunków międzynarodowych, nie daje dużych możliwości znalezienia odpowiednich miejsc do ich odbywania. Wydział Politologii i Studiów Międzynarodowych UMK ma ograniczoną paletę instytucji i przedsiębiorstw, do których kieruje na praktyki, dlatego zazwyczaj studenci szukają ich na własną rękę. Aż 41 proc. ankietowanych oceniło pomoc uczelni w znalezieniu praktyk źle i bardzo źle ${ }^{9}$, więc wskazane byłoby większe zaangażowanie wydziału na tym polu. Ponieważ badania, na których autor opiera artykuł, miały jedynie charakter sondażowy, w przyszłości celowe byłoby rozdzielenie pytań o staże i praktyki, nie ma bowiem pewności, do czego odnosili się studenci. Można tylko domniemywać, że w przypadku słuchaczy drugiego stopnia odpowiedzi dotyczyły staży. Krajowe, a szczególnie zagraniczne staże na Wydziale Politologii i Studiów Międzynarodowych są ofertą skierowaną do wąskiej grupy wyraźnie zainteresowanych konkretnym obszarem stosunków międzynarodowych lub pracą w administracji samorządowej, np. w biurach współpracy z zagranicą.

9 Stosunkowo mało tu było ocen studentów drugiego stopnia, co najpewniej należy thumaczyć faktem, że nie mają ich już w programie studiów. 
Bardzo istotne było ustalenie, jakie obszary tematyczne chciałyby poruszać na zajęciach osoby kończące studia. W rozmowach prywatnych absolwenci kierunku wielokrotnie wspominali, że niektórych zagadnień było w programie zbyt dużo (np. historii dyplomacji czy integracji europejskiej), podczas gdy inne traktowane były marginalnie (chociażby migracje ludności czy zagadnienia dotyczące Trójmorza). Z obszarów badawczych, które miałyby być podstawą nowych programów i wprowadzanych zgodnie z nimi przedmiotów, respondenci wskazywali przede wszystkim:

- przedmioty dotyczące współczesnego bezpieczeństwa międzynarodowego,

- przedmioty dotyczące obszaru Europy Środkowo-Wschodniej,

- przedmioty dotyczące handlu zagranicznego.

We wskazaniach widać pewne różnice między studentami pierwszego i drugiego stopnia - przedmioty związane $z$ handlem zagranicznym wybierali na przykład częściej studenci drugiego stopnia, co może wynikać z faktu, że mają już konkretne plany co do kariery zawodowej związanej z handlem. Słuchacze pierwszego stopnia chętniej wskazywali natomiast zajęcia w języku angielskim.

Generalnie zainteresowanie bezpieczeństwem międzynarodowym i sprawami gospodarczymi jest znacznie bardziej widoczne wśród magistrantów. Uwagę studentów przyciągają także zagadnienia odnoszące się do obszarów Azji i Pacyfiku, co może się wiązać z rosnącą rolą Chińskiej Republiki Ludowej i coraz częstszymi doniesieniami medialnymi na jej temat, także w kontekście nuklearnym Korei Północnej czy obecnej w Polsce dyskusji o Nowym Jedwabnym Szlaku. Poza tym - być może ze względu na kierunki polityki zagranicznej Polski po 2015 r. - wzrasta zainteresowanie naszym regionem. Ogólnie jednak obszar postsowiecki nie budzi wśród studentów entuzjazmu, być może ze względu na fakt, że odnosi się do niego spora część programu, ze szczególnym uwzględnieniem Ukrainy, Republiki Białorusi oraz krajów bałtyckich. Mało interesująca jest też dla respondentów tematyka integracji europejskiej i prawa międzynarodowego. Przyczyną takiego stanu rzeczy może być obecność w programie Stosunków Międzynarodowych dość dużej liczby przedmiotów związanych z tymi zagadnieniami, a uznawanych za trudne do zaliczenia. Nie ma też zainteresowania klasyczną historią dyplomacji, natomiast sporo badanych uznaje za ciekawe zagadnienia związane z historią poszczególnych krajów i regionów.

Ostatnie pytanie $\mathrm{w}$ ankiecie dotyczyło umiędzynarodowienia kierunku Stosunki Międzynarodowe. Szczególnie zaskakujące jest to, że opcję ,więcej programów wyjazdów na studia zagraniczne (jak Erasmus + )" wskazywali 
studenci drugiego stopnia. W związku z programem studiów z tego rodzaju wyjazdów korzystają przede wszystkim słuchacze drugiego roku studiów licencjackich. Statystyki osób korzystających z wyjazdów niestety maleją. Wyraźnie wzrasta natomiast liczba obcokrajowców przyjeżdżających w ramach programu Erasmus+, a nieznacznie - obcokrajowców studiujących na Wydziale Politologii i Studiów Międzynarodowych odpłatnie. Studenci pierwszego stopnia jako istotną wskazali opcję „krótkie wyjazdy na zajęcia zagraniczne (jak wyjazdy studyjne, szkoły letnie)" (58 proc.), prawdopodobnie ze względu na mobilność, ale także koszty wyjazdów. Dla studentów drugiego stopnia taka forma umiędzynarodowienia nie jest szczególnie interesująca, prawdopodobnie ze względu na niższą mobilność, gdyż właśnie na tym etapie nauki wielu z nich pracuje. Bardziej interesują ich praktyki zagraniczne, choć program studiów nie przewiduje ich na drugim stopniu.

\section{Zakończenie}

Od lat liczba studentów prowadzonego na Wydziale Politologii i Studiów Międzynarodowych UMK kierunku Stosunki Międzynarodowe spada. Nie wpływa na to raczej program studiów, ponieważ badania pokazują, że podejmujący studia są zadowoleni z oferty. Ulega ona ciągłym modyfikacjom, a priorytetem jest dostosowanie treści do zmian zachodzących $\mathrm{w}$ otoczeniu międzynarodowym. W toku studiów realizowane są różnorodne przedmioty ${ }^{10}$, w szczególności poruszające problematykę Unii Europejskiej, państw regionu i wschodnich sąsiadów Polski. Studentów coraz częściej interesują też nowe obszary - przede wszystkim Azja i Pacyfik. Gorzej wygląda natomiast ocena praktyki dydaktycznej. Pewne uwarunkowania instytucjonalne, jak wielkość grup ćwiczeniowych czy koszty zajęć w językach obcych, powodują, że studenci nie są z niej dostatecznie zadowoleni i chcieliby iść w kierunku zmian: zajęć warsztatowych, laboratoryjnych czy nowych form nauczania. Wpisuje się to także w oczekiwania interesariuszy, którzy liczą nie tylko na wiedzę fachową studentów i absolwentów, ale także na umiejętność pracy w grupie, rozwiązywania problemów, a więc kompetencje miękkie.

Jeżeli natomiast chodzi o kwestię umiędzynarodowienia studiów, to z jednej strony należy stwierdzić, że oferta zajęć prowadzonych przez specjalistów

10 Zob. Stosunki międzynarodowe, „Uniwersytet Mikołaja Kopernika w Toruniu. Wydział Politologii i Stosunków Międzynarodowych" [online, dostęp: 7 VI 2019], dostępny w internecie: <https://www.wpism.umk.pl/student/programy-studiow/stosunki-miedzynarodowe/>. 
z zagranicy jest stosunkowo niewielka, co wiąże się przede wszystkim z zarobkami proponowanymi naukowcom i dydaktykom, z drugiej jednak część studentów nie chce zapisywać się na zajęcia w językach obcych. $\mathrm{Z}$ badań wynika, że należy tu raczej poszukiwać innych form, jak choćby krótkie wyjazdy studyjne.

\section{Bibliografia}

Historia, „Wydział Politologii UMCS” [online, dostęp: 10 VI 2019], dostępny w internecie: $<\mathrm{https}: / /$ www.umcs.pl/pl/historia,586.htm>.

Jezior J., Metodologiczne problemy zastosowania skali Likerta w badaniach postaw wobec bezrobocia, „Przegląd Socjologiczny” 2013, t. 62, nr 3.

Nauka o stosunkach międzynarodowych $i$ studia europejskie w Polsce, red. J. Czaputowicz, K. Ławniczak, A. Wójciuk, Wydawnictwo Naukowe „Scholar”, Warszawa 2015.

O Instytucie Studiów Międzynarodowych UWr, „Uniwersytet Wrocławski” [online, dostęp: 10 VI 2019], dostępny w internecie: <https://www.ism.uni.wroc.pl/Instytut/O-Instytucie-Studiow-Miedzynarodowych-UWr>.

$O$ wydziale, „Uniwersytet Mikołaja Kopernika w Toruniu. Wydział Politologii i Stosunków Międzynarodowych" [online, dostęp: 10 VI 2019], dostępny w internecie: <https://www. wpism.umk.pl/wydzial/o-wydziale/>.

Stosunki międzynarodowe, „Uniwersytet Mikołaja Kopernika w Toruniu. Wydział Politologii i Stosunków Międzynarodowych" [online, dostęp: 7 VI 2019], dostępny w internecie: $<$ https://www.wpism.umk.pl/student/programy-studiow/stosunki-miedzynarodowe/>. 